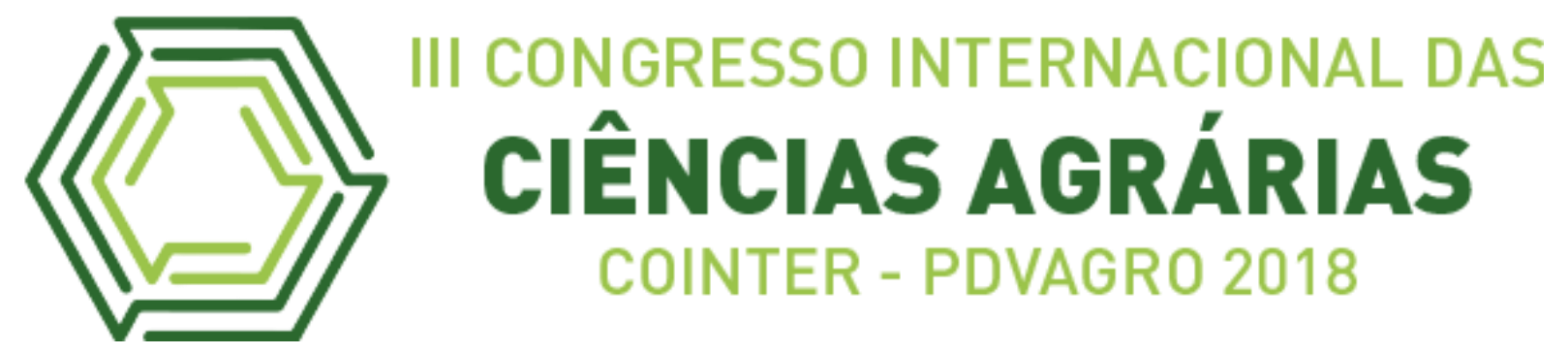

\title{
PRÁTICA DE ENSINO: REFEXÕES A CERCA DA FORMAÇÃO DOCENTE E O DESAFIO EM SER PROFESSOR/A
}

\section{TEACHING PRACTICE: REFLECTIONS ABOUT TEACHING TRAINING AND THE CHALLENGE IN TEACHING/A}

\author{
Apresentação: Relato de Experiência
}

Cristiane Maria dos Santos $\operatorname{Costa}^{1}$; Rubenice Maria de Freitas ${ }^{2}$; Ricardo Torres da Silva $^{3}$; Gizelia Barbosa Ferreira ${ }^{4}$; Mércia Cardoso da Costa Guimarães ${ }^{5}$

DOI: https://doi.org/10.31692/2526-7701.IIICOINTERPDVAGRO.2018.00760

\section{Introdução}

O profissional da educação no pensamento popular é um ser dotado de um dom que surge em algum momento da vida e que os torna capaz de educar, mudar a vida de seus/suas alunos/alunas e os transportar para um mundo de grandes conhecimentos. Diante desse discurso populista da educação Catani (1998) afirma que ao iniciar uma vida de docente o sentido inicial é familiarizar-se com as significações pessoais e sociais de sua formação e a noção adquirida torna-se a proposta da carreira docente.

$\mathrm{Na}$ formação docente Soares e Cunha (2010) afirmam que a formação não deve ser confundida com outros conceitos, como educação, ensino, treino etc., pois envolve, necessariamente, uma dimensão pessoal de desenvolvimento humano global. Os setores da sociedade sofrem constantes modificações que requerem novos métodos de ensino aprendizagem, posturas, ideias, profissionais, crenças e valores que estão além dos conhecimentos tecnicistas das escolas, essas transformações exigem diretamente do setor educacional, cobrando uma maior participação efetiva dos sujeitos (SANTOS; BESNOSIK, 2014). Os autores apresentados possuem uma postura que exalta a formação docente, pois é a partir dela que o/a docente pode refletir sobre suas ações, criar maneiras mais racionais e adequadas, evitando a reprodução mecânica do magistério.

\footnotetext{
${ }^{1}$ Bacharelado em Agronomia, IFPE campus Vitória, cristianemscosta01@ gmail.com

2 Bacharelado em Agronomia, IFPE campus Vitória, rubynha1995@ gmail.com

${ }^{3}$ Bacharelado em Agronomia, IFPE campus Vitória, ricardotorres.torres@ hotmail.com

${ }^{4}$ Professora do IFPE campus Vitória, Doutoranda em Médio Ambiente y Sociedad, Intituto Federal de Pernambuco, Gizelia.ferreira@ vitória.ifpe.edu.br

${ }^{5}$ Professora do IFPE campus Vitória, Doutora em Engenharia Agrícola, UFCG-PB, mercia.guimaraes@ vitoria.ifpe.edu.br
} 
Este é o relato de uma experiência obtida durante o $4^{\circ}$ período do curso de Licenciatura em ciências agrárias que possibilitou desenvolver atividades, realização de laboratórios de ensino e observações de unidades de ensino, tendo este trabalho como objetivo expor as observações da relação do/da educador/educadora e seu/seu educando/educanda, como ocorre a relação interpessoal em sala de aula, em busca da promoção da construção do conhecimento através da formação da consciência crítica que contribuíram para minha formação docente.

\section{Relato de Experiência}

Esta experiência foi vivência em três momentos distintos o primeiro que consiste no estudo e construção e um referencial teórico sobre a formação docente, sem dúvida foi um momento desafiador pois, percebemos um pouco da dimensão e do compromisso enquanto futura docente analisando de forma critica os grandes mestres da educação e os pensamentos reflexivos acerca da formação docente e o compromisso com a sociedade.

Na segunda ação foi realizada uma observação da estrutura física e social da unidade de ensino, pois é necessário saber o contexto em que o/a educando/educanda está inserido, com isso observou-se que as condições necessárias ao aprendizado no ensino agrícola estão condizentes com o esperado, pois a estrutura física e social esta condizente com a proposta oficializada no Projeto Político Pedagógico (PPP) da instituição em que expressa o objetivo de buscar a qualidade do ensino público. A organização escolar apresentada no PPP exalta a qualidade dos servidores desde os técnicos administrativos aos professores, constatado isso durante o período de estágio e levado como temática de discussão nos laboratórios de aula para aclarar as questões hierárquicas nas instituições de ensino, que através deste momento foi importante ter uma nova visão do papel das instituições enquanto profissional ver o quanto esse ambiente influencia no processo de ensino-aprendizagem, que muitas vezes enquanto alunos não percebemos.

E no terceiro momento foi a realização do laboratório de ensino que consistiu no aprofundamento das práticas educativas que seriam observadas a campo, nesse momento duas situações eram expostas a de ouvinte e avaliador onde os colegas eram avaliados seguindo um roteiro, e a outra situação quando se passa a ser o professor, que é mais complexo e prazeroso pois neste momento se percebe a responsabilidade de ser um agente estimulador do 
conhecimento e promotor da formação critica.

\section{Considerações}

A vivência desta experiência permitiu adequação dos conhecimentos das práticas educativas, formação docente e o funcionamento da gestão escolar, sendo um período de imersão numa preparação para a vida acadêmica, apresentando métodos e técnicas da construção de uma aula, autorreflexão sobre os conhecimentos adquiridos e a importância da nossa adequação a sala de aula, sendo o laboratório a oportunidade para conhecermos e corrigirmos tais métodos educativos.

\section{Referências}

CATANI, D. B. Práticas de Formação docente. In: BUENO, B. O. et al. A vida e o oficio dos professores: formação continua autobiografia e pesquisa em colaboração. São Paulo: Escrituras, 1998.

SANTOS, L. T., BESNOSIK, M. H. R. O Espanhol como Língua Estrangeira no Brasil Contemporâneo: Diretrizes e Políticas de Difusão e Formação de Professores. In: LOPES, A., CAVALCANTE, M. A. S., OLIVEIRA, D. A., HYPÓLITO, A, M. (Orgs).Trabalho Docente e Formação: Políticas, Práticas e Investigação: Pontes para a Mudança. CIIE - Centro de Investigação e Intervenção Educativas. Jan 2014.

SOARES, R. S., CUNHA. M. I. Formação do Professor: a docência universitária em busca de legitimidade. Salvador: EDUFBA, 2010. 134 p. ISBN 978-85-232-1198-1. SCiELO Books. Disponível em:< http://books.scielo.org/id/cb/pdf/soares-9788523206772.pdf > Acesso em: 11 de jun de 2018. 